\title{
Kommentar
}

\section{Barn med hyppige feberepisoder}

Olbjørn \& Fjærli omtaler på en lærerik måte hvordan de stilte diagnosen familiær middelshavsfeber hos et barn med hyppige feberepisoder.

Hvis et barn har gjentatte feberepisoder, bør man i tillegg til infeksjonsutredning vurdere om atopisk, malign, autoimmun eller annen kronisk sykdom kan være årsaken. Det er også viktig å utelukke syklisk nøytropeni. Kun sjelden foreligger det periodisk febersyndrom, som er en gruppe sykdommer i det medfødte immunforsvar karakterisert ved spontane inflammatoriske episoder uten forekomst av autoantistoffer. Periodisk feber med aftøs stomatitt, faryngitt og cervikal adenitt (PFAPA-syndrom), familiær middelshavsfeber, mevalonatkinasemangel, også kalt hyper-IgD-syndrom, og TNF-reseptorassosiert autoinflammatorisk syndrom klassifiseres som autoinflammatoriske. Ved flere andre autoinflammatoriske syndromer er feberen noe mindre fremtredende, som ved kuldeindusert autoinflammatorisk syndrom og Muckle-Wells' syndrom. Bortsett fra PFAPA-syndromet skyldes hver av disse sykdommer en kjent genetisk defekt (1).

Febersyndromene debuterer oftest i barnealder med gientatte feberepisoder, utslett, polyserositt (peritonitt, pleuritt, artritt), adenitt og en rekke andre manifestasjoner (1). Under anfallene ses det en økning av akuttfasereaktanter og hvite blodceller, mellom anfallene normaliseres prøvene og mange er helt uaffisert (1). Det er stor overlapping i kliniske manifestasjoner, og det er en utfordring å stille en eksakt diagnose (2).

PFAPA-syndromet, som tidligere er omtalt i Tidsskriftet av Øymar \& Kristoffersen, er sannsynligvis det hyppigst forekommende febersyndrom på våre breddegrader (3). Årsaken er ukjent. Selv om sykdommen kan være meget belastende, er prognosen god, idet plagene opphører i sen barnealder. Tonsillektomi har god effekt hos de fleste. En nærliggende differensialdiagnose er residiverende tonsillitt, som dog sjelden forekommer så regelmessig og som regel er forbundet med flere infeksjonstegn.

Det viste seg at Olbjørn \& Fjærlis pasient hadde familiær middelshavsfeber. Dette syndromet følger autosomalt recessiv arvegang og er forårsaket av en mutasjon i $M E F V$-genet (1). $M E F V$ koder for pyrin, som spiller en viktig rolle i reguleringen av proinflammatoriske cytokiner, som IL-1 $\beta$, og det er påvist mer enn 70 forskjellige mutasjoner i dette genet. Familiær middelshavsfeber forekommer hyppigst blant armenere, arabere, tyrkere og nordafrikanske folkegrupper, og hos disse kan bærerfrekvensen være meget høy. Det er vist at etnisitet, magesmerter, oppkast, diaré, utslett og leddsmerter er blant de faktorer som best skiller febersyndromene med bakgrunn i en genetisk defekt fra PFAPA-syndromet (2). Nettopp det at barnet hadde bakgrunn fra Midtøsten, kombinert med feberepisoder, kraftige magesmerter og leddsmerter, sannsynliggjorde familiær middelshavsfeber. Diagnosen ble bekreftet med homozygot påvisning av den hyppigste mutasjonen M649V, som er assosiert med mer alvorlig sykdom (1). En eksakt diagnose er viktig, fordi kolkisin kan forebygge anfall og sekundær amyloidose hos de fleste som er rammet av sykdommen. Genetisk diagnostikk for familiær middelshavsfeber gjøres ved laboratorium for medisinsk genetikk, Oslo universitetssykehus, Ullevål, mens det ikke er etablert noe tilbud om genetisk diagnostikk av de øvrige autoinflammatoriske sykdommer i Norge.

\section{Henrik Døllner}

henrik.dollner@ntnu.no

Barne- og ungdomsklinikken

St. Olavs hospital

7006 Trondheim

Oppgitte interessekonflikter: Ingen

Litteratur

1. Gattorno M, Federici S, Pelagatti MA et al. Diagnosis and management of autoinflammatory diseases in childhood J Clin Immunol 2008; 28 S73-83.

2. Gattorno M, Caorsi R, Meini A et al. Differentiating PFAPA syndrome from monogenic periodic fevers. Pediatrics 2009; 124: e721-8.

3. Øymar K, Kristoffersen EK. Periodisk feber-syndrom hos barn. Tidsskr Nor Lægeforen 2007; 127 $1651-3$.

Manuskriptet ble mottatt 2.12. 2009 og godkjent 10.12. 2009. Medisinsk redaktør Odd Terje Brustugun. 